Journal of Medical Virology

WILEY

\title{
Comparison of the PapilloCheck assay with the Digene HC2 HPV DNA assay for the Detection of 13 High-Risk Human Papillomaviruses in Cervical and Anal Scrapes.
}

\begin{tabular}{|c|c|}
\hline Journal: & Journal of Medical Virology \\
\hline Manuscript ID: & JMV-11-2327.R1 \\
\hline Wiley - Manuscript type: & Research Article \\
\hline $\begin{array}{r}\text { Date Submitted by the } \\
\text { Author: }\end{array}$ & 19-Apr-2011 \\
\hline Complete List of Authors: & $\begin{array}{l}\text { Didelot, Marie-Noelle; University Hospital } \\
\text { Boulle, Nathalie; University Hospital } \\
\text { Damay, Audrey; University Hospital } \\
\text { Costes, Valérie; University Hospital } \\
\text { Segondy, Michel; University Hospital }\end{array}$ \\
\hline Keywords: & HPV, Papillocheck, HC2 \\
\hline
\end{tabular}

\section{SCHOLARONE Manuscripts}




\section{Title}

Comparison of the PapilloCheck ${ }^{\circledR}$ assay with the Digene HC2 HPV DNA assay for the Detection of 13 High-Risk Human Papillomaviruses in Cervical and Anal Scrapes.

Shortened title
Comparison of PapilloCheck with HC2

Marie-Noelle Didelot ${ }^{1,2}$, Nathalie Boulle ${ }^{1}$, Audrey Damay ${ }^{1}$, Valérie Costes ${ }^{1}$, and Michel Segondy ${ }^{1,2}$,

${ }^{1}$ Department of Biology and Pathology, Montpellier University Hospital, and ${ }^{2}$ INSERM U.1058, Montpellier France

\footnotetext{
*Correspondence to: Dr Michel Segondy, Pôle Biologie-Pathologie, Laboratoire de Virologie, Hôpital Saint-Eloi, CHU Montpellier, 34295 Montpellier cedex 05, France.

E-mail: m-segondy@chu-montpellier.fr
} 


\begin{abstract}
The PapilloCheck ${ }^{\circledR}$ assay was compared with the Digene HC2 HPV DNA assay for the detection of 13 high-risk human papillomaviruses (HPV) in 240 samples, including 181 cervical scrapes and 59 anal scrapes. Overall, 75 (30.5\%) samples were positive by the Digene HC2 HPV DNA assay: 34 (18.8\%) cervical scrapes and 41 (69.5\%) anal scrapes. By considering only the 13 high-risk HPV types detected by the Digene HC2 HPV DNA assay, $66(27.5 \%)$ samples were positive by the PapilloCheck ${ }^{\circledR}$ assay: $27(14.9 \%)$ cervical scrapes and $39(66.1 \%)$ anal scrapes. Concordant results between the two assays were obtained for $225(93.8 \%)$ samples with a Kappa coefficient value of 0.85 , indicating an excellent agreement. By considering all the HPV types detectable by the PapilloCheck ${ }^{\circledR}$ assay, the overall prevalence of HPV was 34.2\% (82/240): $21.0 \%$ (38/181) in cervical scrapes and $74.6 \%$ (44/59) in anal scrapes. Among the samples positive by the PapilloCheck ${ }^{\circledR}$ assay, a multiple HPV infection (2 to 9 HPV types) was identified in 43 of $82(52.4 \%$ ) samples, including 7 of $38(18.4 \%)$ cervical samples, and 36 of $44(81.8 \%)$ anal samples. The prevalence of high-risk HPV, as determined by the PapilloCheck ${ }^{\circledR}$ assay, was $17.6 \%$ $(36 / 205)$ in samples with normal cytology, $83.9 \%$ (26/31) in samples with low-grade squamous intraepithelial lesions or atypical squamous cells of undetermined significance, and $100 \%(4 / 4)$ in samples with high-grade squamous intraepithelial lesions. The results obtained indicate that the PapilloCheck ${ }^{\circledR}$ assay may be considered as a reliable screening test for HPV detection and typing.
\end{abstract}

Key words: HPV, PapilloCheck, HC2 


\section{INTRODUCTION}

Infection with human papillomaviruses (HPV) is the most common sexually-transmitted infection worldwide. Some HPV types, designed as high-risk HPV, have oncogenic properties, and persistent infection with these viruses may lead to the development of precancerous lesions that may evolve into invasive carcinoma [Muñoz et al., 2006]. High-risk HPV are involved in virtually all cases of cervical cancer [Walboomers et al., 1999] and in $25 \%$ to $100 \%$ of the other anogenital or head and neck cancers, according to the grade and localization of the lesions [Kreimer et al., 2005; De Vuyst et al., 2009].

Detection of high-risk HPV DNA in cervical scrapes allows to identify women at risk of cervical malignancies and it is now established that HPV DNA testing is a powerful tool in cervical cancer screening [Cuzick et al., 2008, Meijer et al., 2008]. HPV DNA testing in anal scrapes has also potential interest for identifying subjects at risk of anal cancer [Berry et al., 2009; Goldstone et al., 2009].

The Digene HC2 HPV DNA assay (Qiagen, Courtaboeuf, France) is based on a chemiluminescent reaction in which HPV DNA binds to an RNA cocktail probe to detect 13 high-risk HPV types: HPV 16, HPV 18, HPV 31, HPV 33, HPV 35, HPV 39, HPV 45, HPV 51, HPV 52, HPV 56, HPV 58, HPV 59, and HPV 68. This test has shown an excellent sensitivity for the detection of precancerous lesions of the cervix [Arbyn et al., 2006], and the Digene HC2 HPV DNA assay is the only HPV test approved by the US Food and Drug Administration (FDA) for cervical cancer screening. However, this test is not designed for the detection of other high-risk or probably high-risk HPV types such as HPV 26, HPV 53, HPV 66, HPV 73, and HPV 82 [Muñoz et al., 2003; 2006]. Furthermore, the Digene HC2 HPV DNA assay test does not distinguish individual HPV types. It is well established that there is a difference in the carcinogenic potential between the different high-risk HPV types [Wheeler et al., 2006]. In particular, HPV 16 and 18 types have the highest relative risks of cervical 
cancer and account for 70\% of all cervical cancer cases [Muñoz et al., 2004; Khan et al., 2005; Smith et al., 2007; Wheeler et al., 2009; Matsumoto et al., 2010]. A similar situation is observed in HPV anal infection and anal cancer [Hoots et al., 2009]. Therefore, HPV tests that distinguish HPV types may identify individuals at the greatest risk of precancerous or cancerous lesions.

The PapilloCheck ${ }^{\circledR}$ test (Greiner Bio-one, Frickenhausen, Germany) is a PCR-based DNA microarray system that allows to identify $24 \mathrm{HPV}$ types, including the 13 high-risk types detected by the Digene HC2 HPV DNA assay, the high-risk types HPV 73 and HPV 82, the probably high-risk types HPV 53 and HPV 66, and the low-risk types HPV 6, HPV 11, HPV 40, HPV 42, HPV 43, HPV 44/55, and HPV 70 (Fig. 1).

The aim of the present study was to compare the Digene HC2 HPV DNA and PapilloCheck ${ }^{\circledR}$ assays for the detection of HPV in cervical and anal scrapes.

\section{MATERIALS AND METHODS}

\section{Clinical specimens}

Cervical scrapes were collected from pregnant women who benefited from cervical cytology and HPV DNA testing during their pregnancy. Their mean $( \pm \mathrm{SD})$ age was $26.6( \pm 4.4)$ years. Anal scrapes were collected from HIV-1-seropositive men who have sex with men who benefited from anal cancer screening. Their mean $( \pm$ SD) age was $43.5( \pm 7.8)$ years. Cervical scrapes were collected using a Cervex ${ }^{\circledR}$ brush (Cytyc, Montrouge, France) and anal scrapes were collected using a Scrinet ${ }^{\circledR} 3 \mathrm{~mm}$ brush (Laboratoire CDD, Paris, France). Brushes were agitated vigorously in a vial of PreservCyt transport solution (Cytyc), and the resulting cell suspension was stored at room temperature until analysis.

\section{Cytological analysis}


Thin layer cytological smears were prepared from the cell suspension vial by controlled membrane transfer technology using the ThinPrep 2000 processor (Cytyc). After Papanicolaou staining, slides were examined by a pathologist and interpreted based on the Bethesda 2001 system criteria established for cervical cytology [Smith, 2002]. Cervical and anal smears were interpreted as normal, atypical cells of undetermined significance, lowgrade squamous intraepithelial lesions, or high-grade squamous intraepithelial lesions.

\section{Digene HC2 HPV DNA assay}

The Digene HC2 HPV DNA assay was carried out on a 4-ml aliquot of the residual cell suspension according to the manufacturer's instructions. A relative light unit (RLU) cut-off value of 1.0 or greater was considered positive for high-risk HPV detection.

\section{PapilloCheck ${ }^{\circledR}$ assay}

The PapilloCheck ${ }^{\circledR}$ assay is based on the PCR amplification of a DNA fragment of about 350 nucleotides within the E1 gene of HPV. The primers used also generate a PCR product from the PCR control template which is present in the assay mastermix. An internal PCR control is included which targets a region within the human housekeeping gene ADAT1 (Adenosine deaminase tRNA specific 1) which is amplified and fluorescence-labelled with Cy5 simultaneously in the same reaction. The amplification products are then hybridized to specific DNA probes fixed on the DNA chip. Each HPV type is detected by a specific DNA probe present in 5 replicates in each chip. After hybridization and subsequent washing, the chip is scanned with the CheckScanner ${ }^{\mathrm{TM}}$ (Greiner Bio-one) at excitation wavelenghts of 532 and $635 \mathrm{~nm}$.

Sample testing using the Papillocheck ${ }^{\circledR}$ assay was carried out following the manufacturer's recommendations. Briefly, DNA was extracted from $100 \mu \mathrm{l}$ of the residual cell suspension 
using the MagNa Pure Compact Nucleic Acid Isolation kit (Roche Diagnostics, Meylan, France) on a MagNa Pure Compact automated nucleic acid extractor, with a final elution in $200 \mu 1$ of elution buffer. PCR was carried out using $5 \mu 1$ of DNA extract in a final volume of $25 \mu 1$ with the PapilloCheck ${ }^{\circledR}$ mastermix and $1 \mathrm{U}$ of HotStart Taq DNA polymerase (Qiagen, Courtaboeuf, France). PCR conditions were: $15 \mathrm{~min}$ at $95^{\circ} \mathrm{C}$ followed by 40 cycles of $30 \mathrm{sec}$ at $95^{\circ} \mathrm{C}, 25 \mathrm{sec}$ at $55^{\circ} \mathrm{C}$, and $45 \mathrm{sec}$ at $72^{\circ} \mathrm{C}$, followed by 15 cycles of $30 \mathrm{sec}$ at $95^{\circ} \mathrm{C}$ and 45 sec at $72^{\circ} \mathrm{C}$. For hybridization, $5 \mu \mathrm{l}$ of the PCR product was mixed with $30 \mu \mathrm{l}$ of the hybridization buffer and $25 \mu \mathrm{l}$ of the mix were transferred into a compartment of the chip. The chips were washed 3 times with the washing solution at room temperature $(10 \mathrm{sec}), 50^{\circ} \mathrm{C}$ $(60 \mathrm{sec})$ and then at room temperature $(10 \mathrm{sec})$. After drying by centrifugation, these chips were scanned using the Checkscanner ${ }^{\mathrm{TM}}$. Data were analyzed and results interpreted with the Checkreport $^{\mathrm{TM}}$ version 3.0.1 software.

\section{Sequencing}

Samples giving a discordant result between the two assays were analyzed by sequencing. A fragment of the L1 gene was amplifified by PCR using the PGMY consensus primers [Gravitt et al., 2000]. The amplification mixtures contained 10 pmol of each oligonucleotide in the upstream and downstream primer sets in the presence of 1x PCR buffer, $4 \mathrm{mM} \mathrm{MgCl}_{2}, 200$ $\mu$ mol (each) dNTPs, 1,5 U of AmpliTaq gold DNA polymerase (Applied Biosystems, Courtaboeuf, France) and $5 \mu 1$ of DNA extract in a volume of $50 \mu 1$. The PCR conditions were $95^{\circ} \mathrm{C}$ for $9 \mathrm{~min}$ followed by 40 cycles of $95^{\circ} \mathrm{C}$ for $1 \mathrm{~min}, 55^{\circ} \mathrm{C}$ for $1 \mathrm{~min}$ and $72^{\circ} \mathrm{C}$ for $1 \mathrm{~min}$, and a final extension at $72^{\circ} \mathrm{C}$ for $5 \mathrm{~min}$. PCR Products were analyzed by electrophoresis on a $2 \%$ agarose gel stained with ethidium bromide. PCR products of the expected size (450 bp) were sequenced. The GP5+ and GP6+ primers [de Roda Husman et al., 1995] served as forward and reverse sequencing primers, respectively. Sequencing was performed using the 
BigDye ${ }^{\circledR}$ Terminator v3.1 cycle sequencing kit (Applied Biosystems, Courtaboeuf, France) on an ABI PRISM ${ }^{\circledR} 3500$ genetic analyzer (Applied Biosystems). Sequences were aligned using the Lasergene ${ }^{\circledR}$ sequence analysis software (DNAstar, Madison, WI) and then compared through BLAST to HPV reference sequences using GenBank database (http://www.ncbi.nlm.nih.gov/blast). HPV type identification was based on a sequence similarity with an identified HPV type greater than $90 \%$.

\section{Data analysis}

When the Digene HC2 HPV DNA assay was positive, the two assays were considered as concordant if one or more of the 13 HR-HPV types detected by the Digene HC2 HPV DNA assay was identified by the PapilloCheck ${ }^{\circledR}$ assay. When the Digene HC2 HPV DNA assay was negative the two assays were considered as concordant if none of these 13 HR-HPV types was identified by the PapilloCheck ${ }^{\circledR}$ assay.

Agreement between the two tests was assessed by the Cohen's kappa coefficient, with values of 0.00 to 0.20 indicating poor agreement, 0.21 to 0.40 indicating fair agreement, 0.41 to 0.60 indicating moderate agreement, 0.61 to 0.80 indicating good agreement, and 0.81 to 1.00 indicating excellent agreement.

The prevalences of high-risk HPV DNA detection, multiple HPV infection and cytological abnormalities were compared between cervical and anal specimens using the Khi2 test. $P<$ 0.05 was considered as significant.

\section{RESULTS}

A total of 240 samples, including 181 cervical scrapes and 59 anal scrapes were analysed by the two assays. Overall, 75 (30.5\%) samples were positive with the Digene HC2 HPV DNA assay: $34(18.8 \%)$ cervical scrapes and $41(69.5 \%)$ anal scrapes. By considering only the 13 
high-risk HPV types detected by the Digene HC2 HPV DNA assay, 66 (27.5\%) samples were positive by the PapilloCheck® assay: 27 (14.9\%) cervical scrapes and 39 (66.1\%) anal scrapes. By considering all the HPV types detectable by the PapilloCheck ${ }^{\circledR}$ assay, the overall prevalence of HPV was 34.2\% (82/240): 21.0\% (38/181) for cervical scrapes and $74.6 \%$ (44/59) for anal scrapes. The HPV type distribution is presented in Fig 2. Among the samples positive by the PapilloCheck ${ }^{\circledR}$ assay, a multiple HPV infection (2 to 9 HPV types) was identified in 43 of $82(52.4 \%)$ samples: 7 of 38 (18.4\%) cervical scrapes and 36 of $44(81.8 \%)$ anal scrapes.

As shown in Table 1, 225 (93.8\%) samples gave concordant results in both assays, with a Kappa coefficient value of 0.85 , indicating an excellent agreement. Samples giving a discordant results are presented in Table 2. Genotype identification determined by sequencing in the discordant samples was in agreement with the results obtained by the PapilloCheck ${ }^{\circledR}$ assay.

Among the cervical scrapes, cytological abnormalities were observed in 8 (4.4\%) samples: 3 $(1.7 \%)$ atypical squamous cells of undetermined significance, $4(2.2 \%)$ low-grade squamous intraepithelial lesions and $1(0.5 \%)$ high-grade squamous intraepithelial lesions. Among the anal scrapes, cytological abnormalities were observed in 27 (45.8\%) samples: 6 (10.2\%) atypical squamous cells of undetermined significance, 18 (30.5\%) low-grade squamous intraepithelial lesions and $3(5.1 \%)$ high-grade squamous intraepithelial lesions. The prevalence of high-risk HPV (13 types), as determined by the PapilloCheck ${ }^{\circledR}$ assay, was $17.6 \%(36 / 205)$ in samples with normal cytology, $83.9 \%(26 / 31)$ in samples with low-grade squamous intraepithelial lesions or atypical squamous cells of undetermined significance, and $100 \%$ (4/4) in samples with high-grade squamous intraepithelial lesions. As shown in Table 3, the prevalence of high-risk HPV in samples with normal cytology was much higher in anal scrapes than in cervical scrapes $(\mathrm{P}<0.0001)$. Cytological abnormalities were observed in 3 
of $12(25 \%)$ samples found positive by the Digene HC2 HPV DNA assay but negative by the PapilloCheck ${ }^{\circledR}$ assay for the detection of the HPV types targeted by the Digene HC2 HPV DNA assay (Table 2).

The differences observed between cervical and anal scrapes in the prevalence of high-risk HPV DNA detection, multiple HPV infection, and cytological abnormalities were highly significant $(\mathrm{P}<0.0001$ for all three variables $)$.

\section{DISCUSSION}

In the present study, the PapilloCheck ${ }^{\circledR}$ assay was compared with the FDA-approved Digene HC2 HPV DNA assay for the detection of 13 high-risk HPV types in cervical and anal scrapes. An excellent agreement (93.8\%) between the two assays was observed. This is in accordance with other studies that reported a high agreement between the PapilloCheck ${ }^{\circledR}$ assay and the Digene HC2 HPV DNA assay [Dalstein et al., 2009; Halfon et al., 2010; Schopp et al., 2010] or other HPV tests such as the linear array [Dalstein et al., 2009; Halfon et al., 2010], the GP5+/6+ PCR enzyme immunoassay [Jones et al., 2009; Hesselink et al., 2010], the PGMY09/11 PCR line blot assay and the SPF10 PCR line probe assay [Schopp et al., 2010]. The discrepant results were due mainly to a cross-reactivity of the Digene HC2 HPV DNA assay with HPV types other than those theoretically detected by the assay. Indeed, the Digene HC2 HPV DNA assay was positive in samples in which HPV 53, HPV 66 or HPV 42 were detected by both the PapilloCheck ${ }^{\circledR}$ assay and sequencing. A cross-reactivity of the Digene HC2 HPV DNA assay with these HPV types as well as with other oncogenic or non-oncogenic HPV types such as HPV types $26,61,67,71$ or 81 has been previously reported [Castle et al., 2002; 2008; Poljak et al., 2002]. Three other cervical samples were positive by the Digene HC2 HPV DNA assay but negative by the PapilloCheck ${ }^{\circledR}$ assay, one 
of them being positive for HPV 66 by sequencing, another one being negative by sequencing, whereas the third sample could not be tested by sequencing.

In the present study, cross-reactivity in the Digene HC2 HPV DNA assay was observed mainly with HPV 53 and HPV 66. Given the fact that these two HPV types are considered now as probably oncogenic [Muñoz et al., 2006], this cross-reactivity is not a real problem for cervical or anal cancer screening. Indeed in the present study, cytological abnormalities were observed in 3 samples giving a cross-reactivity with HPV 53 and/or HPV 66.

As expected, results obtained from cervical and anal samples were highly different. Indeed, the prevalences of high-risk HPV detection, multiple HPV infection and cytological abnormalities were considerably higher in the anal scrapes than in the cervical ones. This difference reflects the fact that HIV-1-infected men who have sex with men are at high risk of anal HPV infection and HPV-associated anal precancerous lesions [Chin-Hong et al., 2008; Damay et al., 2010]. The high prevalence of high-risk HPV in anal samples with normal cytology observed in the present study is in agreement with previous studies [Fox et al., $2005]$.

In summary, results from the present study demonstrate a high agreement between the Digene HC2 HPV DNA assay and the PapilloCheck® assay for the detection of 13 high-risk HPVs. However, cross-reactivities with untargeted HPV genotypes may be observed with the Digene HC2 HPV DNA assay. The main advantages of the PapilloCheck® assay is HPV type identification, detection of more HPV oncogenic and non-oncogenic types as compared with the Digene HC2 HPV DNA assay, as well as identification of multiple HPV infections. The risk of progression of HPV-associated lesions to precancerous or cancerous lesions varies with HPV types [Khan et al., 2005; Wheeler et al., 2009; Matsumoto et al., 2010]. Therefore, HPV genotyping is useful for identifying patients at increased risk of cancer development 
[Meijer et al., 2006]. The PapilloCheck ${ }^{\circledR}$ assay may thus be considered as a reliable screening test for HPV detection and typing. 


\section{REFERENCES}

Arbyn M, Sasieni P, Meijer CJLM, Clavel C, Koliopoulos G, Dillner J. 2006. Clinical applications of HPV testing: a summary of meta-analysis. Vaccine 24 suppl.3:78-89.

Berry JM, Palefsy JM, Jay N, Cheng SC, Darragh TM, Chin-Hong PV. 2009. Performance characteristics of anal cytology and human papillomavirus testing in patients with highresolution anoscopy-guided biopsy of high-grade anal intraepithelial neoplasia. Dis Colon Rectum 52:239-247.

Castle PE, Schiffman M, Burk RD, Wacholder S, Hildesheim A, Herrero R, Bratti MC, Sherman ME, LorinczA. 2002. Restricted cross-reactivity of hybrid capture 2 with nononcogenic human papillomaviruses types. Cancer Epidemiol Biomarkers Prev 11:1394-1399.

Castle PE, Solomon D, Wheeler CM, Gravitt PE, Wacholder S, Schiffman M. 2008. Human papillomavirus genotype specificity of hybrid capture 2. J Clin Microbiol 46:2595-2604.

Chin-Hong PV, Berry JM, Cheng SC, Catania JA, Da Costa M, Darragh TM, Fishman F, Jay N, Pollack LM, Palefsky JM. 2008. Comparison of patient- and clinician-collected anal cytology samples to screen for human papillomavirus-associated anal intraepithelial neoplasia in men who have sex with men. Anal Intern Med 149:300-306.

Cuzick J, Arbyn M, Sankaranarayanan R, Tsu V, Ronco G, Mayrand MH, Dillner J, Meijer CJLM. 2008. Overview of human papillomavirus-based and other novel options for cervical cancer screening in developed and developing countries. Vaccine 26 Suppl. 10:K29-K41.

Dalstein V, Merlin S, Bali C, Saunier M, Dachez R, Ronsin C. 2009. Analytical evaluation of the PapilloCheck test, a new commercial DNA chip for detection and genotyping of human papillomavirus. J Virol Methods 156:77-83. 
Damay A, Fabre J, Costes V, Didelot JM, Didelot MN, Boulle N, Segondy M. 2010. Human papillomavirus (HPV) prevalence and type distribution, and HPV-associated cytological abnormalities in anal specimens from men infected with HIV who have sex with men. J Med Virol 82:592-596.

de Roda Husman AM, Walboomers JMM, van den Brule AJC, Meijer CJLM, Snijders PJF. 1995. The use of general primers GP5 and GP6 elongated at their 3' ends with adjacents highly conserved sequences improves human papillomavirus detection by polymerase chain reaction. J Gen Virol76:1057-1062.

De Vuyst H, Clifford GM, Nascimento MC, Madeleine MM, Franceschi S. 2009. Prevalence and type distribution of human papillomavirus in carcinoma and intraepithelial neoplasia of the vulva, vagina and anus: a meta-analysis. Int J Cancer 124:1626-1636.

Fox PA, Seet JE, Stebbing J, Francis N, Barton SE, Strauss S, Allen-Mersh TG, Gazzard BG, Bower M. 2005. The value of anal cytology and human papillomavirus typing in the detection of anal intraepithelial neoplasia: a review of cases from an anoscopy clinic. Sex Transm Infect 81:142-146.

Goldstone SE, Enyinna CS, Davis TM. 2009. Detection of oncogenic human papillomavirus and other predictors of anal high-grade dysplasia in men who have sex with men with abnormal cytology. Dis Colon Rectum 52:31-39.

Gravitt PE, Peyton CL, Alessi TQ, Wheeler CM, Coutlée F, Hildesheim A, Schiffman MH, Scott DR, Apple RJ. 2000. Improved amplification of genital human papillomaviruses. J Clin Microbiol 38:357-361.

Halfon P, Benmoura D, Khiri H, Penaranda G, Blanc B, Riggio D, Sandri MT. 2010. Comparison of the clinical performance of carcinogenic HPV typing of the Linear Array and Papillocheck HPV-screenig assay. J Clin Virol 47:38-42. 
Hesselink AT, Heideman DA, Berkhof J, Topal F, Pol RP, Meijer CJ, Snijders PJ. 2010. Comparison of the clinical performance of PapilloCheck human papillomavirus detection with that of the GP5+/6+-PCR enzyme immunoassay in population-based cervical screening. J Clin Microbiol 48:797-801.

Hoots BE, Palefsky JM, Pimenta JM, Smith JS. 2009. Human papillomavirus type distribution in anal cancer and anal intraepithelial lesions. Int J Cancer 124:2375-2383.

Jones J, Powell NG, Tristram A, Fiander AN, Hibbits S. 2009. Comparison of the PapilloCheck DNA micro-array Human Papillomavirus detection assay with Hybrid Capture II and PCR-enzyme immunoassay using the GP5+/6+ primer set. J Clin Virol 45:100-104.

Khan MJ, Castle PE, Lorincz AT, Wacholder S, Sherman M, Scott DR, Rush BB, Glass AG, Schiffman M. 2005. The elevated 10-year risk of cervical precancer and cancer in women with human papillomavirus (HPV) type 16 or 18 and the possible utility of type-specific HPV testing in clinical practice. J Natl Cancer Inst 97:1072-1079.

Kreimer AR, Clifford GM, Boyle P, Franceschi S. 2005. Human papillomavirus types in head and neck squamous cell carcinomas worldwide: a systematic review. Cancer Epidemiol Biomarkers Prev 14:467-475.

Matsumoto K, Oki K, Furuta R, Maeda H, Yasugi T, Takatsuka N, Mitsuhashi A, Fujii T, Hirai Y, Iwasaka T, Yaegashi N, Watanabe Y, Nagai Y, Kitagawa T, Yoshikawa H. 2010. Predicting the progression of cervical precursor lesions by human papillomavirus genotyping: a prospective cohort study. Int J Cancer (Epub ahead or print)

Meijer CJLM, Berkhof J, Castle PE, Hesselink AT, Franco EL, Ronco G, Arbyn M, Bosch FX, Cuzick J, Dillner J, Heideman DAM, Snijders PJF. 2008. Guidelines for human papillomavirus DNA test requirements for primary cervical cancer screening in women 30 years and older. Int J Cancer 124:516-520. 
Meijer CJ, Snijders PJ, Castle PE. 2006. Clinical utility of HPV genotyping. Gynecol Oncol 103:12-17.

Muñoz N, Bosch FX, Castellsagué X, Diaz M, de Sanjosé S, Hammouda D, Shah KV, Meijer CJ. 2004. Against which human papillomavirus types shall we vaccinate and screen? The international perspective. Int J Cancer 111:278-285.

Muñoz N, Bosch X, de Sanjose S, Herrero R, Castellsague X, Shah KV, Snijders PJF, Meijer CJL. 2003. Epidemiologic classification of human papillomavirus types associated with cervical cancer. N Engl J Med 348: 518-527.

Muñoz N, Castellsagué X, Berrington de Gonzalez A, Gissmann L. 2006. HPV in the etiology of human cancer. Vaccine 24 suppl.3:1-10.

Poljak M, Marin IJ, Seme K, Vince A. 2002. Hybrid capture II HPV test detects at least 15 human papillomavirus genotypes not included in its current high-risk probe cocktail. J Clin Virol 25 Suppl.3:S89-S97.

Schopp B, Holz B, Zago M, Stubenrauch F, Petry KU, Kjaer SK, Iftner T. 2010. Evaluation of the performance of the novel PapilloCheck HPV genotyping test by comparison with two other genotyping systems and the HC2 test. J Med Virol 82:605-615.

Smith JH. 2002. Bethesda 2001. Cytopathology 13: 4-10.

Smith JS, Lindsay L, Hoots B, Keys J, Franceschi S, Winer R, Clifford GM. 2007. Human papillomavirus type distribution in invasive cervical cancer an high-grade cervical lesions: a meta-analysis update. Int J Cancer 121:621-632.

Walboomers JMM, Jacobs MV, Manos MM, Bosch FX, Kummer JA, Shah KV, Snijders PJF, Peto J, Meijer CJLM, Munoz N. 1999. Human papillomavirus is a necessary cause of invasive cervical cancer worldwide. J Pathol 189: 12-19. 
Wheeler CM, Hunt WC, Joste NE, Key CR, Quint WGV, Castle PE. 2009. Human papillomavirus genotype distributions: implications for vaccination and cervical screening in the United States. J Natl Cancer Inst 101:475-487.

Wheeler CM, Hunt WC, Schiffman M, Castle PE. 2006. Human papillomavirus genotypes and the cumulative 2-year risk of cervical precancer. J Infect Dis 194:1291-1299. 
TABLE 1. Agreement between the HC2 HPV DNA assay and the PapilloCheck® assay for the detection of 13 high-risk HPV types

\begin{tabular}{lccc}
\hline & \multicolumn{2}{c}{ PapilloCheck } \\
& Positive & Negative \\
\hline HC2 & Positive & 63 & 12 \\
& & & 162 \\
\hline
\end{tabular}


TABLE 2. Discordant results between the HC2 HPV DNA assay and the PapilloCheck ${ }^{\circledR}$ assay

\begin{tabular}{|c|c|c|c|c|}
\hline Sample no. & $\overline{\mathrm{HC2}}$ & PapilloCheck & Sequencing & $\overline{\text { Cytology }}$ \\
\hline \multicolumn{5}{|l|}{ Cervical } \\
\hline $\mathrm{C} 27$ & Positive & HPV 53 & ND & Normal \\
\hline $\mathrm{C} 38$ & Positive & Negative & Negative & Normal \\
\hline $\mathrm{C} 45$ & Positive & HPV 53 & HPV 53 & Normal \\
\hline $\mathrm{C} 55$ & Positive & HPV 66 & HPV 66 & LSIL \\
\hline $\mathrm{C} 82$ & Positive & HPV 53 & HPV 53 & Normal \\
\hline C105 & Negative & HPV 58 & ND & Normal \\
\hline C136 & Positive & HPV 53, HPV 70 & HPV 53 & LSIL \\
\hline C141 & Negative & HPV 16 & HPV 16 & Normal \\
\hline $\mathrm{C} 145$ & Positive & Negative & HPV 66 & Normal \\
\hline $\mathrm{C} 162$ & Positive & Negative & ND & Normal \\
\hline C165 & Positive & HPV 42 & HPV 42 & Normal \\
\hline \multicolumn{5}{|l|}{ Anal } \\
\hline A13 & Negative & HPV 31, HPV 73 & ND & Normal \\
\hline A29 & Positive & HPV 53, HPV 66 & HPV 66 & ASCUS \\
\hline A39 & Positive & HPV 53 & HPV 53 & Normal \\
\hline A50 & Positive & HPV 66 & HPV 66 & Normal \\
\hline
\end{tabular}

ASCUS, atypical squamous cells of undetermined significance; LSIL, low-grade squamous intraepithelial lesions; ND, not done. 
TABLE 3. Prevalence of high-risk HPV (13 types), as determined by the PapilloCheck ${ }^{\circledR}$ assay, according to the cytological findings.

\begin{tabular}{lcc}
\hline & \multicolumn{2}{c}{ Samples } \\
\cline { 2 - 3 } Cytology & Cervical & Anal \\
\hline Normal & $21 / 173(12.1 \%)$ & $15 / 32(46.9 \%)$ \\
LSIL/ASCUS & $5 / 7(71.4 \%)$ & $21 / 24(87.5 \%)$ \\
HSIL & $1 / 1(100 \%)$ & $3 / 3(100 \%)$ \\
\hline
\end{tabular}

ASCUS, atypical squamous cells of undetermined significance; LSIL, low-grade squamous intraepithelial lesions; HSIL, high-grade squamous intraepithelial lesions. 


\section{Figure legend}

Fig.1. HPV types detected by the Digene HC2 HPV DNA assay and the PapilloCheck ${ }^{\circledR}$ assay.

Fig. 2. Distribution of HPV types in cervical $(n=181)$ and anal $(n=59)$ scrapes as detected by the PapilloCheck ${ }^{\circledR}$ assay. Asterisks indicate the 13 high-risk HPV types targeted by the Digene HC2 HPV DNA assay. Solid circles indicate additional high-risk or probably highrisk HPV types. 
HPV types detected by the Digene HC2 HPV DNA assay and the PapilloCheck assay. $254 \times 190 \mathrm{~mm}(96 \times 96 \mathrm{DPI})$ 


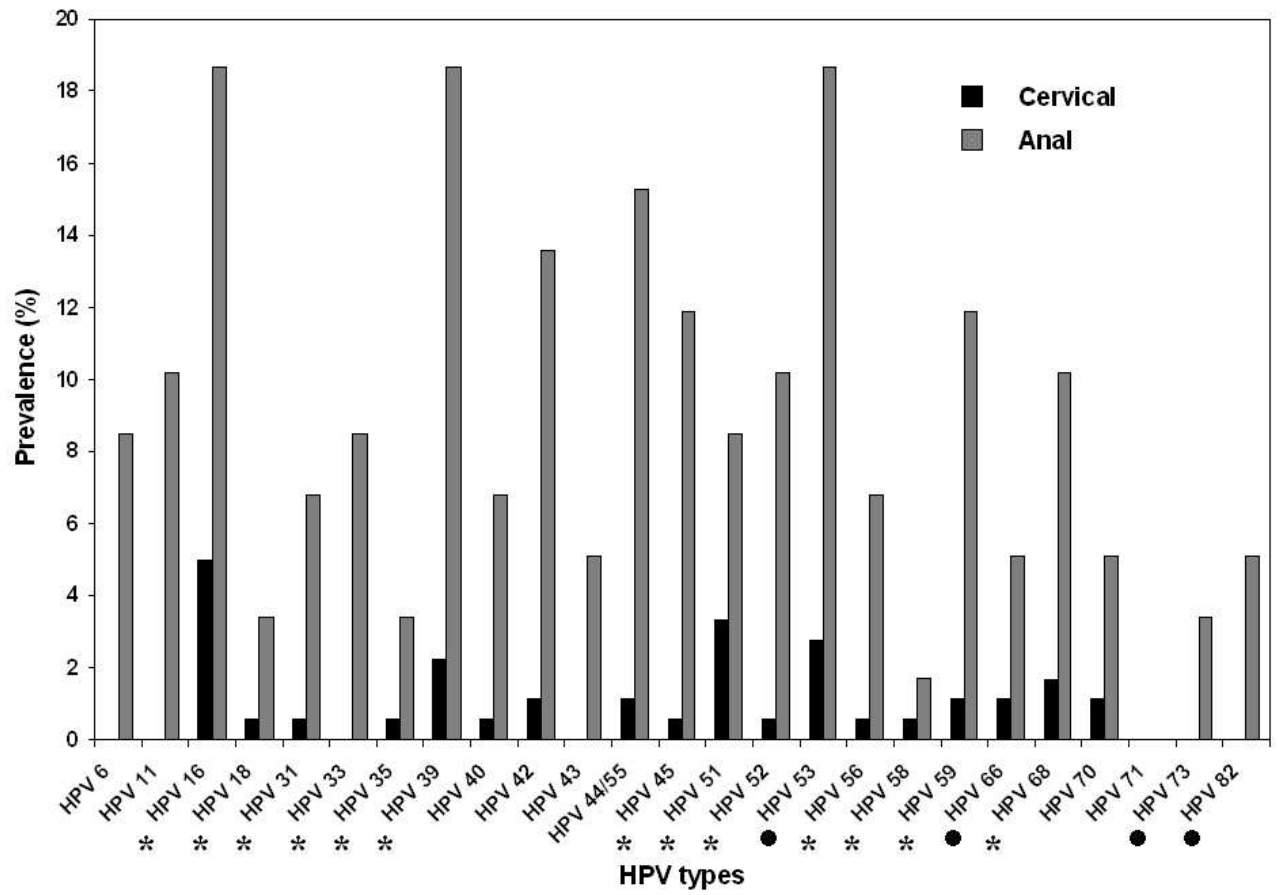

Distribution of HPV types in cervical $(n=181)$ and anal $(n=59)$ scrapes as detected by the PapilloCheck assay. Asterisks indicate the 13 high-risk HPV types targeted by the Digene HC2 HPV DNA assay. Solid circles indicate additional high-risk or probably high-risk HPV types. $254 \times 190 \mathrm{~mm}(96 \times 96 \mathrm{DPI})$ 